\title{
Investigating the Relationship Between Financial Integration and Economic Growth in the East African Community
}

\author{
Onesmus Mutunga Nzioka \\ $\mathrm{PhD}$ Candidate and Tutorial fellow, University of Nairobi, Kenya
}

doi: 10.19044/esj.2017.v13n19p249 URL:http://dx.doi.org/10.19044/esj.2017.v13n19p249

\begin{abstract}
This study set out to investigate the relationship between financial integration and economic growth in the EAC community states. Secondary data on financial integration and GDP was obtained from worldbank and the East African Community(EAC) community secretariat. The data was subjected to simple linear regression and correlation analysis to achieve the set objective. The study found that, Gross capital flow to GDP (financial openness) is positively correlated to economic growth ( $r=0.2093, \mathrm{p}<0.05)$. The study also found that, $3.98 \%$ of the variations in economic growth, as measured by GDP per capita, within the countries are explained by financial integration, as measured by the ratio of gross capital flows, $38.98 \%$ of the variations in economic growth between the countries are explained by financial integration while $4.38 \%$ of the variations in economic growth of the East African commmenityEAC as an economic bloc (considering panel data) are explained by financial integration. The findings confirm that, when capital flows increase, economic growth also increases, pointing to the necessity of the East African member states to explore ways of increasing the capital flows between the countries. The researcher recommends conducting of a comparative study between the old and the new EAC to establish whether the inclusion of Rwanda and Burundi, has had any positive impact (catalyzed) on the level of financial integration and economic growth.
\end{abstract}

Keywords: Economic growth, financial integration, Africa

\section{Introduction}

\section{Background to the Study}

International financial integration occurs when exchange controls are removed and the capital account is freed to allow financial resources to flow freely in and out of the country. With the increased degree of international financial integration around the world, many countries especially developing 
countries are now trying to remove cross-border barrier and capital control, relaxing the policy on capital restrictions and deregulating domestic financial system. Trichet (2005) argues that, financial integration fosters financial development, which in turn creates potential for higher economic growth.

Financial integration enables the realization of economies of scale and increases the supply of funds for investment opportunities. The actual integration process also stimulates competition and the expansion of markets, thereby leading to further financial development. In turn, financial development can result in a more efficient allocation of capital as well as a reduction in the cost of capital. At the same time, financial integration is blamed for increasing a country's vulnerability to international financial crises, which tend to occur during periods of sudden reversals in international capital flows.

The conceptualization of this study was based on the following four theories;Hegemonic SstabilityTtheory, optimum currency area, purchasing power parity theory and the efficient market hypothesis. Heather, et al. (2004) argues that, trans-border integration is driven and shaped by powerful states rather than by forces endogenous to markets. The concept of purchasing power parity contends that, prices of similar goods ought to be the same in different currencies or that exchange rate changes should offset international differences in price movements or inflation rates (Rogoff, 1996). The originators of the Optimum Currency Area (OCA) define a common currency area in terms of the extent of trade and factor mobility. Mundell (1961), McKinnon (1963), and Kenen (1969) seek to show that an economy's characteristics should be a determinant of its exchange-rate regime.Fama (1970) first defined the term efficient market as one in which security prices fully reflects all available information. The market is efficient if the reaction of market prices to new information should be instantaneous and unbiased.The presence of a hegemon, prices being similar, having a single currency and markets being efficient would lead to more integrated markets, less volatility and hence increased economic growth.

In theory, there are various direct and indirect channels through which increased financial flows can enhance growth. The direct channels include augmentation of domestic savings, reduction in the cost of capital through better global allocation of risk, development of the financial sector (Levine (1997) and Caprio and Honohan (1999)), and transfer of technological know-how. The main indirect channels are associated with promotion of specialization (Kalemli-Ozcan, Sorensen, and Yosha (2003)) and inducement for better economic policies (Jeanne (2003)).

Edison et al (2002) examine the relationship between International Financial Integration (IFI) and economic growth data over 20-25 years for 57 countries. Constructing a variety of measures of IFI, the study concluded that 
the dataset does not support the view that international Financial Integration promotes economic growth after controlling for specific economic, financial, institutional and policy characteristics. However, they note that, international Financial Integration is positively associated with real per capital.

Empirical studies are inconclusive on the effect of financial integration on growth. Some studies give the result that, FDI inflows, which could arguably be stimulated by an open financial system, are positively associated with economic growth when countries are sufficiently rich, educated or financially developed (Blomstrom et al.1994). Quinn (1997) shows that, capital account openness is robustly positively correlated with long-run economic growth in 64 countries for 1958 to 1989, whereas Arteta et al.(2001) and Kraay (1998) indicate that, capital account liberalization is as likely to hurt as to help growth.

There are well-established theoretical explanations suggesting a positive impact coming from the process of progressive financial openness. Nevertheless, in principle, the opposite direction of influence could be also assumed: more dynamic economies, with high expectations of profitable investment activities could attract more (domestic as well as foreign) financial flows (Guiso et al. 2004).

Njoroge (2010) examined the impact of economic integration on growth by constructing an economic integration index based on an average of most favoured nations tariffs and the level of regional cooperation for COMESA, EAC and SADC. The economic integration index developed by the study captured two main aspects that facilitate economic integration. First, it considered trade reforms within a particular trade bloc capturing the various efforts of individual member countries towards freer trade. Second, trade reforms by a particular trade bloc and with the rest of the world, capturing efforts at a trade bloc level to freer trade were considered. Overall findings of the study were that, economic integration had a positive and significant impact on growth.

Osada and Saito (2010), studied the effects of financial integration on economic growth using a comprehensive panel dataset of 83 international countries from 1974to 2007. Their study made use of defacto measures of financial integration broadly categorized as stocks of external assets and liabilities. The findings of their study suggest that, the effects of financial openness on economic growth vary substantially depending on the type of external assets and liabilities. The justification Osada and Saito gave for this outcome was that, an increase in external assets may lead to a relocation of production units from the country that owns those assets to other countries.

Another set of empirical studies suggests that, the composition of capital flows determines the effects of financial integration on economic growth (Reisen and Soto (2001) and Goldberg (2004)). In particular, these 
studies conclude that, FDI flows tend to be positively associated with output growth in those countries that have well-developed domestic financial markets (Alfaro, Chanda, Kalemli-Ozcan, and Sayek (2003)). Other studies focus on the impact of equity market liberalization on the growth rates of output and investment. Bekaert, Harvey, and Lundblad (2001) find that, equity market liberalization induces a significant increase in the growth rate of output and Henry (2000) documents that, it leads to a substantial increase in the growth rate of investment.

\section{Summary of Literature Review and Research Gaps}

Although the relationship between the constructs in this study have been empirically tested in other studies, their conceptualization and contextualization have varied from this study. Conceptually, the debate on the influence of financial integration on economic growth is inconclusive given that some empirical studies have yielded inconsistent results. Some indicate a positive relationship (Edison et al (2002) while others show that the effects vary substantially (Osada and Saito (2010). Contextually, studies on how financial integration influences the economic growth of the East African community are also not conclusive(Njoroge (2010)).

\section{Research Problem}

The concept of international financial integration (or financial integration) refers to the specific links of a country with international capital markets (Prasad et al. 2003). In other words, international financial integration can be likened to the opening of domestic financial systems, such as financial markets and institutions and banking systems, to the rest of the world and the internationalization of financial assets and liabilities managed by resident entities. Barro (2001) revealed that, financial instability leads to drops in economic growth. This weak growth is the result of excessive capital inflows and outflows and, more generally, the instability of net financial flows (Prasad et al., 2003; World Bank, 2000) and IMF, 2001). Indeed, financial instability can also impact on the poverty level and have other consequences for the social situation (World Bank, 2000).

The East African Community (EAC) is keen on improving the standard of living of the population through increased competitiveness, value addition in production, trade and investment. Sustainable development of the envisaged economic bloc can be promoted, through the improved standards of living(http://www.statistics.eac).However, the East African Community continues to experience low economic performance mainly attributed to a number of factors. These factors include the countries inability, like many other African countries, to secure access to larger markets, inherent high intra-country trade costs, lack of an effective framework for regional 
cooperation and resource pooling and the pressure from development partners pursuing their own foreign policy objectives in the continent (Njoroge, 2010). As a way of addressing these challenges, the EAC has over the years embarked on widening and deepening the cooperation among member states through the process of regional integration. In pursuit of this goal, the EAC has attached great importance to financial sector development. One of the pillars of this effort as enumerated in Chapter 14 of EAC treaty is the pursuit of financial integration with a view to maximizing the ability of financial sectors to mobilize resources and efficiently allocate them to productive sectors of the region.

The empirical studies on the relationship between financial integration and economic growth have yielded inconsistent results. Those which indicate a positive relationship include; ((Edison et al (2002), (Blomstrom et al.(1994)). Quinn (1997), (Borenzstein, De Gregorio, and Lee (1998) $)$ and (Alfaro, Chanda, Kalemli-Ozcan, and Sayek (2003))—_ Studies by Osada and Saito (2010), Arteta et al.(2001) and Kraay (1998) among others show that, the results are ambiguous. The study by IMF (2002) indicates a negative relationship. This inconsistency is the conceptual gap which the current study seeks to fill by answering the following research question: What is the relationship between financial integration and economic growth in the East African community?

\section{Research Objective}

The objective of the study was to investigate the relationship between financial integration and economic growth in the EAC.

\section{Research methodology \\ Introduction}

This section presents the research methodology applied in this study. It discusses the research philosophy in section 3.2, research design in section 3.3 and the population and sample size in section 3.4. The data collection methods and research procedures are outlined in section 3.6, as section 3.7 discusses the data analysis techniques adopted in the study.

\section{Research Philosophy}

To guide the research effort, a researcher requires an appropriate research philosophy. Selection of research philosophy has a choice between four options: positivism, constructivism or interpretivism, advocacy participatory and pragmatism.

This study was anchored on a positivism research philosophy because it is based on existing theory and it formulated quantitative hypotheses that 
were tested. The positivist paradigm allowed for deriving the relationship between financial integration and Economic growth in the EAC.

\section{Research Design}

Three broad classifications of non-experimental research designs are identified as exploratory research design, descriptive research design and causal (explanatory) research designs. The causal survey design seeks to establish the cause and effect relationship between two or more variables.

The study sought toestablish the relationship between financial integration and economic growth.It was therefore justifiable to use the causal (explanatory), survey research design in the study because the objectives sought to establish the cause and effect relationships between several variables.

\section{Population of the Study}

The East African Community (EAC) is the regional intergovernmental organization of the Republics of Burundi, Kenya, Rwanda, the United Republic of Tanzania, and the Republic of Uganda, with its headquarters in Arusha, Tanzania. All these republics are technically referred to as the five member/partner states in the EAC. For inclusivity, the population of interest was all the five partner states in the EAC.

EAC was chosen as the context of the study because its primary objective is to develop a single market and investment area in East Africa that is anchored on the twin pillars of internal free trade and liberal trade with the rest of the world.

\section{Data Collection}

The study used secondary data for the period (1963to 2014). Several landmark initiatives by the East African community have been operationalized over this period. This makes it necessary to consider the entire period for purposes of capturing the impact of all the initiatives undertaken towards the integration of the respective economies.

Annual data on gross capital flows, broad money supply (M2), Annual GDP figures, growth rate in GDP per capita and total credit to the private sector was retrieved from the respective partner state central bank databases, the national statistical organs, the East African community secretariat and the international monetary fund and the world bank. .

\section{Data Analysis and Diagnostic Tests}

Measures of central tendency (Arithmetic mean) as well as measures of dispersion (the range, coefficient of variation and standard deviation)were applied on all the indicators to provide a comparative situation analysis for 
all the five member states. For this analysis, broad money supply, gross capital flows, exports, imports, inflation, exchange rates and total credit to the private sector were converted to a common currency (US dollars).

The variables were further subjected to regression analysis and correlation analysis using panel data in order to achieve each of the five objectives. However, before estimating the statistical model to address the study objective, the researcher first conducted a panel unit root test to establish whether there were any variables in the model that were nonstationary. The Im- Pesaran-Test (IPS) panel unit root test was conducted.

\section{DATA DESCRIPTION AND ANALYSIS Introduction}

This section presents the findings of the study based on correlation analysis of the various variables considered in the study. Section 4.2 discusses correlation analysis and 4.3discusses the diagnostic tests (the unit root test) as necessary conditions to be satisfied before conducting regression analysis.

\section{Multicollinearity Test}

Before carrying out the correlation analysis, multicollinearity test was conducted to establish the possibility and extend of linear dependence between the variables. The details are provided below.

The results presented in Table 4.3 shows that, the mean variance inflation factor (VIF) was estimated at 1.47, which is greater than the critical value of 1. It's called the VIF because it estimates how much the variance of a coefficient is "inflated" because of linear dependence with other predictors. Thus, a VIF of 1.47 tells us that the variance (the square of the standard error) of a particular coefficient is $47 \%$ larger than it would be, if that predictor was completely uncorrelated with all the other predictors.

As indicated in Table 4.3, no VIFs were greater than 10. This demonstrates absence of strong multicollinearity. In addition, the variables with high VIFs are private bank credit to GDP and M2/GDP which are control variables, and the variables of interest do not have high VIFs. Hence we can safely ignore multicollinearity. Measures of distribution such as skewness and kurtosis which are usually incorporated in the Jargue Bera statistic for normality test were not computed. The reason for omitting these measures was because the assumption of a normally distributed error term is held in estimation under ordinary least squares (OLS). However, this study utilized the generalized two-stage least square (G2SLS) random-effects instrumental variable method (REIVM). 
Table 4.1: Variance Inflation Factor Test for Multicollinearity

\begin{tabular}{|c|c|c|}
\hline Variable & VIF & $1 /$ VIF \\
\hline Private Bank Credit to GDP & 2.02 & 0.4955 \\
\hline M2/GDP & 1.79 & 0.5589 \\
\hline Gross capital flow to GDP & 1.58 & 0.6313 \\
\hline Mean VIF & 1.47 & \\
\hline
\end{tabular}

Author: Researcher (2015)

\section{Correlation Analysis}

The researcher proceeded to analyze the correlation between each of the variables to ascertain the direction of association and its statistical significance as presented in table 4.3 below, after the discussion of the results.

\section{Economic Growth and Financial Integration}

Gross capital flow to GDP (financial openness) is positively and significantly correlated to economic growth $(\mathrm{r}=0.2093$, $\mathrm{p}<0.05)$. These findings were similar to those established by Edison et al (2002) who concluded that, international financial integration is positively associated with real per capital. Njoroge (2010) arrived at similar findings that, economic integration had a positive and significant impact on growth.Blomstrom et al(1994),Quinn (1997), De Gregorio and Lee (1998)), Alfaro, Chanda, Kalemli-Ozcan, and Sayek (2003) arrived at similar findings, as well.

Table 4.2: Pairwise Correlation coefficients for the Variables

\begin{tabular}{|c|c|c|c|c|}
\hline & $\begin{array}{c}\text { Economic } \\
\text { growth }\end{array}$ & $\begin{array}{c}\text { Gross capital } \\
\text { flows to GDP }\end{array}$ & $\begin{array}{c}\text { Ratio of M2 } \\
\text { to GDP }\end{array}$ & $\begin{array}{c}\text { Private Bank } \\
\text { Credit to GDP }\end{array}$ \\
\hline Economic growth & 1 & & & \\
\hline $\begin{array}{c}\text { Gross capital } \\
\text { flows to GDP }\end{array}$ & $0.2093^{*}$ & 1 & & \\
\hline & 0.0007 & & & \\
\hline $\begin{array}{c}\text { Ratio of M2 to } \\
\text { GDP }\end{array}$ & 0.016 & $0.3707^{*}$ & & \\
\hline & 0.7974 & 0.0000 & & \\
\hline $\begin{array}{c}\text { Private Bank } \\
\text { Credit to GDP }\end{array}$ & 0.039 & $0.3606^{*}$ & $0.8333^{*}$ & 1 \\
\hline & 0.5317 & 0.0000 & 0.0000 & \\
\hline
\end{tabular}

* denotes statistical significance at the 5 percent level

Author: Researcher (2015)

\section{Unit Root Tests}

Before estimating the different models to address the study objectives, the researcher first conducted a panel unit root test to establish whether there were any variables in the model that were non-stationary. The 
Im- Pesaran-Test (IPS) panel unit root test was conducted. The test allows for individual effects, time trends and common time effects. It is based on the mean of the individual Dickey-Fuller (DF) t-statistics of each unit in the panel, and assumes that all series are non-stationary (have unit roots) under the null hypothesis. Table 4.7 gives the summary of the unit root test based on the IPS Test.

Table 4.3: IPS Panel Unit Root Tests

\begin{tabular}{|c|c|c|c|}
\hline & \multicolumn{3}{|c|}{ t-bar Statistic } \\
\hline Variable & Levels & $\begin{array}{c}\text { First } \\
\text { difference }\end{array}$ & $\begin{array}{c}\text { Levels with } \\
\text { time trend }\end{array}$ \\
\hline Gross capital flows to GDP (Financial openness) & -1.9586 & $-9.6123^{*}$ & $-2.8170^{*}$ \\
\hline M2/GDP (Financial Deepening 1) & $-2.4817^{*}$ & $-9.6148^{*}$ & $-3.5410^{*}$ \\
\hline Private Bank Credit to GDP (Financial Deepening 2) & -0.6178 & $-12.3860^{*}$ & $-2.2957^{*}$ \\
\hline Economic growth & $-5.2093^{*}$ & $-10.6814^{*}$ & $-5.8813^{*}$ \\
\hline
\end{tabular}

* denotes statistical significance at the 5 percent level

Author: Researcher (2015)

In the test results presented in Table 4.3, gross capital flows to GDP was non-stationary in levels. Similarly, the ratio of private bank credit to GDP was also non-stationary at levels. However, after including a time trend gross capital flows to GDP and private bank credit to GDP attained stationarity showing that the variables were trend stationary.

\section{Hypotheses testing and discussion of findings}

This study set out to investigate on the relationship between financial integration and economic growth in the EAC.

To achieve this objective, the following hypothesis was tested;

Hypothesis 1: Financial integration has no effect on economic growth.

The hypothesis was tested based on the statistical models specified in the research methodology section (chapter three) as outlined below;

\section{Hypotheses Testing and discussion of findings}

Hypothesis 1: Financial integration has no effect on economic growth.

In order to address the first hypothesis of this study, the dependent variable (economic growth) was regressed against gross capital flow to GDP as the explanatory variable. However, instruments for financial deepening, namely, the ratio of M2 to GDP and the ratio of bank credit to the private sector to GDP were included, hence the generalized two-stage least square (G2SLS) random-effects instrumental variable (IV) was used as the regression model as presented in table 5.1. 
Table 5.1: Financial Integration and Economic Growth

\begin{tabular}{|c|c|c|c|}
\hline G2SLS-REMIV & & $\mathrm{Z}$ & P-Value \\
\hline Economic growth & Coefficient & 0.44 & 0.662 \\
\hline Gross capital flow to GDP & 4.40 & 1.84 & 0.066 \\
\hline Constant & $3.3911^{* *}$ & 0.0398 & \\
\hline R-squared: & Within & 0.3898 & 0.6623 \\
\hline & Between & 0.0438 & P-Value \\
\hline Chi-square statistic $^{72}$ & Overall & 0.19 & \multicolumn{2}{|c|}{ Gross capital flow to GDP } \\
\hline Instrumented: $^{2}$ & Aus & \\
\hline
\end{tabular}

Author: Researcher(2015)

A positive coefficient of 4.40 on gross capital flow to GDP was realized with a p-value of 0.662 which was not statistically significant at the 0.05 level. Hence we fail to reject the hypothesis that, financial integration has no effect on economic growth. This indicates that, financial integration as measured by gross capital flow to GDP is positively associated with economic growth, though it does not have a statistically significant effect on economic growth. The study findings are similar to those by Edison et al (2002) that, international financial integration does not support the view that promotes economic growth, though international financial integration is positively associated with real per capita.

This model means that, the East African member states can achieve an economic growth rate of $3.3911 \%$ in the absence of financial integration and this growth rate can increase by $4.4 \%$ for every $1 \%$ increase in the level of financial integration. Essentially, the presence of financial integration accelerates economic growth.

The $\mathrm{R}^{2}$ values indicate that, $3.98 \%$ of the variations in economic growth, as measured by GDP per capita, within the countries are explained by financial integration, as measured by the ratio of gross capital flows to GDP, 38.98\% of the variations in economic growth between the countries are explained by financial integration while $4.38 \%$ of the variations in economic growth of the East African community as an economic bloc (considering panel data) are explained by financial integration. This would mean that, overall, $95.62 \%$ of the variations in economic growth of the East African community are explained by other factors, other than financial integration, which are not accounted for, in the model above.

The results imply that, the presence of financial integration in an economy leads to improved economic growth. Further, these findings confirm the theoretical relationship documented in the literature and justify 
the correlation results achieved in 4.3.1, explaining the positive significant relationship between financial integration and economic growth. By implication, countries with low level of financial integration or without financial integration are faced by low levels of economic growth compared to the countries with relatively higher levels of financial integration.

\section{Summary of findings, conclusion and recommendations Introduction}

This chapter presents a summary of findings from correlation analysis as well as the study contributions to knowledge and policy recommendations. The chapter also identifies the limitations of the study and future research directions.

\section{Correlation Analysis}

Correlation analysis on the various variables indicated that, Gross capital flow to GDP (financial integration) is positively and significantly correlated to economic growth $(\mathrm{r}=0.2093, \mathrm{p}<0.05)$. The two measures of financial deepening, namely, ratio of M2 to GDP $(r=0.3707, \mathrm{p}<0.05)$ and private bank credit to GDP $(\mathrm{r}=0.3606, \mathrm{p}<0.05)$ are positively and significantly correlated to financial integration.

\section{Relationship between financial integration and economic growth}

In determining the relationship between financial integration and economic growth, hypothesis 1 was tested. The results of testing the hypothesis indicate that, financial integration as measured by gross capital flow to GDP is positively associated with economic growth, though it does not have a significant effect on economic growth. The results imply that, the presence of financial integration in an economy leads to improved economic growth. Therefore, the East African community member states should put more efforts on increasing the capital flows between the member states. This can be achieved by tapping in more investments (capital investments by the governments, foreign direct investments, investments in startup businesses, mutual fund flows with a focus on increasing the net cash additions, the traditional asset classes of cash, stocks and bonds) and trade flows.

\section{Conclusion of the Study}

The failure to reject hypothesis 1indicates that, financial integration as measured by gross capital flow to GDP is positively associated with economic growth, though it does not have a significant effect on economic growth. This leads to the conclusion that, countries with low level of financial integration or without financial integration are faced by low levels 
of economic growth compared to the countries with relatively higher levels of financial integration.

\section{Policy Recommendations and Implications}

The findings of this study are useful to the central banks of the respective East African community member states as well as investors. The positive association between financial integration and economic growth serves to benefit the member states through their respective central banks which are mandated to manage the monetary policy. The control of money supply as measured by M2 should be enhanced by adopting expansionary monetary policy measures in an effort to increase its ratio to GDP. In trying to expand money supply, the central banks could consider lowering the respective countries' reserve ratios, so that the commercial banks have a wider deposit base which enhances the creation of credit money.

They could also consider lowering the discount window which supports increased lending capacity. More importantly, it is advisable for the banking sector to consider increasing lending to the private sector. An effective way to achieve this would be for the respective central banks to put limits on public borrowing from the domestic financial markets (discourage aggressive selling of government securities) and put measures in place to enhance government revenue collection, instead, to meet the budgetary needs. The respective governments could also consider exploring the various sources of money supply and try to enhance them. Key sources of money supply would be individual and corporate savings. Therefore, the East African governments should continue to encourage both individuals and corporates to save more.

The determination of international diversification strategies by international investors depends on the nature and magnitude of the relationships existing between volatility of macro-economic factors and economic growth as well as the level of capital flows between and within the countries involved. The findings of the study support the existence of significant association of financial integration on economic growth. This implies that, increased capital flows are necessary for the growth of the East African community economy.

\section{Limitations of the Study}

There are various challenges that were encountered in the conduct of this study, as a result of the nature of the study, method of analysis, type of data, context as well as time frame. The study was quantitative in nature, narrowing the researcher to focus on only measures that are quantifiable yet a qualitative study or a combination of both would have provided a wider array of variables to be studied, making the research more robust and less 
biased. A similar challenge was posed by the type of data used. The study applied secondary data only, limiting the degree of the accuracy of the study findings to the accuracy of the data. This explains why reliability and validity tests were not carried out but the researcher used credible sources such as World Bank and IMF to collect the data, in an effort to ensure that, the findings are reasonably reliable.

This study was limited to the East African community as the context, a region that is too small on the global map or even continent wise. Therefore, the findings are basically applicable to the region and can only be relevant on the global map as a foundation for similar but more extensive studies. Essentially, the choice of the context was backed by limitation in financial, human as well as time resources; a challenge that is normal in most academic studies. A wider context of the study and use of primary data through interviews or questionnaires which captures more information and attributes of different variables would have only been achievable with more financial resources and investing more time on the research.

\section{References:}

a. Alfaro, Laura, Areen dam Chanda, SebnemKalemli-Ozcan, and SelinSayek, (2004). FDI and Economic Growth: The Role of Local Financial Markets, Journal of International Economics, 64(1), 113-34.

2. Arteta, C., B. Eichengreen and C. Wyplosz (2001). When Does Capital Account Liberalization Help More than it Hurts?,NBER Working Paper, No. 8414.

3. Barro, R. (2001). Economic Growth in Fast Asia before and After the Financial Crisis, NBER Working Paper No 8330 (Cambridge, Massachusetts: National Bureau of Economic Research).

4. Bekaert, Geert, Campbell R. Harvey, and Christian Lundblad, (2001). Emerging Equity Markets and Economic Development, Journal of Development Economics, 66465504.

5. Blomstrom M., R.E. Lipsey, M. Zejan (1994). What Explains Developing CountriesnGrowth?, NBER Working Paper, No. 4132.

6. Caprio, Gerard, and Patrick Honohan, (1999)."Restoring Banking Stability: Beyond Supervised Capital Requirements," Journal of Economic Perspectives, 13(3),43-64.

7. De Gregorio, J., \&Guidotti, P.E. (1995).Financial development and economic growth. World Development, 23(4),433-448. 
Edison, H., Levine, R., Luca R., Sløk, T., (2002).International Financial Integration and Economic Growth.Journal of International Monetary and Finance 21749-7624.

8. Fama, E., (1970). Efficient Capital Markets: A Review of Theory and Empirical Work, Journal of Finance. 25(2), 383 417.

9. Goldberg, Linda, (2004).Financial-Sector FDI and Host Countries: New and Old Lessons, NBER Working Paper No. 10441 (Cambridge, Massachusetts: National Bureau of Economic Research).

10. Guiso, L., Jappelli, T., Padulla, M., \& Pagano, M. (2004). Financial market integration and economic growth in the EU. Economic Policy, 19(5), 523-577.

11. Heather, M.E., Porter, T. and Roberge, I. (2004).Politics or Markets? The determinants of cross integration in the NAFTA and the EU, New Political Economy, 9(3), 325-340.

12. Henry, Peter, (2000). Do Stock Market Liberalization Cause Investment Booms? Journal of Financial Economics, 58(5), 301-34.

13. International Monetary Fund (2001).World Economic Outlook, October, World Economic and Financial Surveys (International Monetary Fund, Washington).

14. Jeanne, O. (2003). Why Do Emerging Market Economies Borrow in Foreign Currency? IMF Working Paper 03/177, Washington, DC.

15. Kalemli-Ozcan, S. and Manganelli, S. (2008).Financial Integration and Risk Sharing: The Role of the Monetary Union, in $5^{\text {th }}$ European Central Banking Conference on The Euro at Ten: Lessons and Challenges, Frankfurt: ECB.

16. Kalemli-Ozcan, S. Sorensen, B.Yosha, O., (2003). Risk Sharing and Industrial Specialization: Regional and International Evidence, American Economic Review 93.

17. Kenen, P. (1969). The Optimum Currency Area: An Eclectic View, In Mundell and Swoboda, (eds.), Monetary Problems of the International Economy, Chicago: University of Chicago Press.

18. Kose, M. A., Prasad, E., Terrones, M., (2004). Volatility and Movement in a Globalized World Economy: An Exploration, forthcoming, in Horst Siebert ed., Macroeconomic Policies in the World Economy, Springer.

19. Kraay, A. (1998), In Search of the Macroeconomic Effects of Capital Account Liberalization, Manuscript, the World Bank. 
20. Levine, R. (1997). Financial development and economic growth: views and agenda, Journal of Economic Literature, 35,688-726.

21. McKinnon, R. (1963), Optimum Currency Areas. American Economic Review, 52, 717-725.

22. Njoroge, L. (2010).The impact of regional integration on economic growth: empirical evidence from COMESA, EAC and SADC trade blocs. American Journal of Social and Management Sciences, 2010, 1(2),150- 163.

23. Osada, M. and Saito M. (2010). Financial Integration and Economic Growth: An Empirical Analysis Using International Panel Data from 1974-2007. Research and Statistics Department, Bank of Japan.

24. Prasad, E., Rogoff, K., Wei, S., Kose, M., (2003). Effects of Financial Globalization on Developing Countries: Some Empirical Evidence, IMF Occasional Paper No. 220(Washington: International Monetary Fund).

25. Quinn, D. (1977), The Correlates of Change in International Financial Regulation, American Political Science Review, 91, 531-51.

26. R. A. Mundell, "The International Disequilibrium System," Kyklos, (1961) (2), 14, 153-72.

27. Reisen, Helmut, and Marcelo Soto, (2001), Which Types of Capital Inflows Foster Developing- Country Growth?,International Finance, 4(1)1-14.

Rogoff, K., (1996), The Purchasing Power Parity Puzzle, Journal of Economic Literature 34: 647-668..

28. Trichet, J.C. (2005), Financial markets integration in Europe: the $\mathrm{ECB}^{\text {ec }}$ s view, BIS Review, 39: 1-5.

29. World Bank (2000),The Quality of Growth, (World Bank: Washington DC). 